\title{
A Note on Terms
}

'British India' is used in this book to indicate all the territory under the formal or informal control of the East India Company and later the British government, including the princely states.

I have used the term 'Indian Mutiny' (rather than an alternative such as 'Indian Rebellion' or 'Anglo-Indian War', which would better indicate the extent of the conflict of 1857-8), because it accurately reflects the view of events held by those writers whose work is discussed. The term 'Anglo-Indian' also reflects nineteenth-century usage, referring to the British community in India.

Place names in English are given in their nineteenth-century forms where these were standard and widely used (Calcutta, not Kolkata). Words transliterated from the indigenous languages of India appear in the form used by the writer in question, with current spellings supplied in parentheses if required. Where place names or personal names appear in several variants (as in the stories of Alauddin's invasion of Chitor in pursuit of Padmini) I use current spellings outside of direct quotations. 
